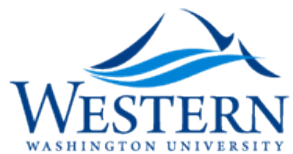

Western Washington University

Western CEDAR

Spring 2000

\title{
No Accident: From Black Power to Black Box Office
}

Bill Lyne

Western Washington University, william.lyne@wwu.edu

Follow this and additional works at: https://cedar.wwu.edu/english_facpubs

Part of the English Language and Literature Commons

\section{Recommended Citation}

Lyne, Bill, "No Accident: From Black Power to Black Box Office" (2000). English Faculty and Staff Publications. 4. https://cedar.wwu.edu/english_facpubs/4

This Article is brought to you for free and open access by the English at Western CEDAR. It has been accepted for inclusion in English Faculty and Staff Publications by an authorized administrator of Western CEDAR. For more information, please contact westerncedar@wwu.edu. 


\section{No Accident: From Black Power to Black Box Office}

It's no accident that people like Malcolm $X$ and Martin Luther King were destroyed at those moments of their political careers when ... they replaced nationalism with a critique of imperialism. (hooks 37)

$\mathrm{T}$ he years between Malcolm $X$ as the scariest thing mainstream white America could imagine and Malcolm X as pitchman for movies, baseball caps, and $t$-shirts have been bleak ones for African American progressive politics. The various movements that held so much promise in the 1950s and '60s have, in the words of Cornel West, "been crushed and/or absorbed" (Keeping 246). Manning Marable has divided black politics into "three strategic visions, which can be termed 'inclusion,' ... 'black nationalism,' and transformation'" ("History" 73). Generally speaking, "inclusion" and "black nationalism" have been defanged and absorbed, while those ideas represented by Malcolm X's "transformationist" last year have been silenced and crushed. Marable notes the way that the silence has been institutionalized when he points out that "most historians [have] characterized the central divisions within black political culture as the 150-year struggle between 'integration' and 'separation' "

("History" 72), with the poles represented in such easy binaries as Du Bois versus Garvey, Martin versus Malcolm, or Henry Louis Gates versus Molefi Asante.

The yin and yang between the inclusionist and nationalist visions has led to the African American political gains of the last fifty years: the end of legal segregation, the increase in the dissemination and study of African American culture, and the grow th of the black middle class. But, at the same time, this political dynamic has also created conditions in which life for the majority of African Americans has become steadily worse. While the African American middle class has been moving to the suburbs, black enrollments in U.S. colleges have declined, real incomes for black workers have dropped through the floor, black life expectancy has gone down, and a staggering percentage of young African American males have been warehoused in prisons. The connections between the African American middle class and lower classes have been broken to the point that the increasing number of high-profile black leaders and elected officials rarely represent the interests of the African American underclass. ${ }^{1}$ Inclusionist and even nationalist political strategies have served the African American middle class with varying degrees of success, but they have done virtually nothing for those left behind in U.S. inner cities. The strategy with the most potential to change the plight of the African American underclass is transformation,
William Lyne is Associate Professor of English at Western Washington University. His work has appeared in PMLA, Arizona Quarterly, and other journals. 
which begins with the fundamental insight that "black economic empowerment is impossible in the long run without a complete shift in the pattern of ownership, the expansion of the rights of labor, and the democratization of the relations of production within U.S. society" ("History" 85).

Marable's formulation leans heavily on the Marxist tradition, but we should be careful not simply to equate transformationism with Marxism. The relationship between black liberation movements and Marxist/socialist movements has been and still is complex, and often antagonistic. ${ }^{2}$ African American transformationist thinkers such as Cornel West, bell hooks, and Audre Lorde often emphasize questions of ethics, culture, and gender that tend to fall into the background of many Marxist analyses. But rather than get bogged down in the distinctions between black transformationism and various Marxisms, let us focus on the underlying dynamic that unites these traditions and clearly separates them from more mainstream liberal strategies. The most important element that transformationism takes from Marxism is an emphasis on sweeping and fundamental change. Unlike integrationist strategies, which seek to expand participation in current arrangements, or nationalist strategies, which seek to replicate current arrangements, transformationist strategies look to create new and different institutions, traditions, and practices. The focus is macro rather than micro, global rather than local. Thus, an NAACP-led civil rights movement that tries to integrate more African Americans into schools, corporations, and elected office, or the Nation of Islam's attempts to create and expand black capitalism, are not transformationist activities. In terms of broad strategic goals, transformationist groups like the National Black United Front or the Black Liberation Army have much more in common with the Democratic Socialists of America or the Socialist Workers Party than they do with the NAACP or the Nation of Islam.
Another crucial fact that separates black transformationist politics from integrationist or nationalist groups is its virtual absence from what passes for political debate in the mainstream U.S. What we call the "radical" black or feminist movements of the 1960s have been successful only insofar as they have fallen back to mostly integrationist positions. For example, over the last thirty years large numbers of women have found positions as both students and professors in U.S. universities that remain solidly patriarchal, racist, capitalist institutions. The U.S. mainstream actively works to exclude transformationist analysis, especially from African Americans. Patricia Williams, in her book The Alchemy of Race and Rights, describes the two ways that black expression is heard:

\begin{abstract}
For blacks, describing needs has been a dismal failure as political activity. It has succeeded only as a literary achievement. The history of our need is certainly moving enough to have been called poetry, oratory, epic entertainment-but it has never been treated by white institutions as the statement of a political priority. (I don't mean to undervalue the liberating power for blacks of such poetry, oratory and epic; my concern is the degree to which it has been compartmentalized by the larger culture as something other than political expression.) Some of our greatest politicians have been forced to become ministers or blues singers. Even white descriptions of "the blues" tend to remove the daily hunger and hurt from need and abstract it into a mood. And whoever would legislate against depression? Particularly something as rich, soulful, and sonorously productive as black expression.... But from blacks, stark statistical statements of need are heard as strident, discordant, and unharmonious. Heard not as political but only against the backdrop of their erstwhile musicality, they are again abstracted to mood and angry sounds. (151-52)
\end{abstract}

Williams's description of the way black expression is heard easily fits an "either/or" model-either something bluesy or soulful, or something discordant and angry. (A paradigmatic instance of this dichotomy is the Sixties 
mainstream media representation of Martin Luther King, Jr., as the harmonious, acceptable black spokesman versus Malcolm $X$ as the angry, unintelligible terrorist.) This binary creates the illusion of multiple and effective voices of dissent. But Williams's analysis shows the way in which a certain position is always not heard. Ralph Ellison is heard as soulful blues, Bigger Thomas is heard as "mood and angry sounds," and the Marxist vision of Richard Wright is silenced. Martin Luther King's Christian non-violence is blues, Malcolm X's Muslim separatist nationalism is angry, the Black Panthers' Marxism is silenced. Black cultural nationalism becomes the necessary, easily demonized and contained Other that gives the illusion of oppositional space, while Black dissent that moves away from race and toward class and economics is excluded from the conversation.

Transformationist strategy has virtually disappeared from U.S. politics over the last twenty-five years, to the point that black leaders like Lani Guinier and Eleanor Holmes Norton have been deemed too left for public service. The last gasp of any organized mainstream political effort to represent the black underclass comes with the unraveling of Jesse Jackson's Rainbow Coalition in the wake of the 1988 Democratic National Convention. This silence has also led to an historical amnesia. Despite its virtual invisibility in mainstream debate, transformationist thinking characterizes the mature work of a long tradition of black intellectuals, most of whom are usually identified as either inclusionists or black nationalists. Frederick Douglass, W.E.B. Du Bois, James Baldwin, Amiri Baraka, Martin Luther King, Jr., and Malcolm X all address issues of class, international economic oppression, and the dynamics of power in their later work. ${ }^{3}$ And yet, in both scholarly discussions and the public imagination, these thinkers tend to emerge easily and completely as either inclusionists (Douglass, Du Bois, Baldwin, King) or black nationalists (Baraka, Malcolm X). In the twentieth century, black thinkers are usually exiled (the state harassment and eventual emigration of Du Bois), reviled and marginalized (the critical descriptions of later Baldwin as bitter and shrill, of later Baraka as boring and irrelevant), or murdered (the assassinations of King and Malcolm X) as they become transformationists.

I continue to be astonished about the extent to which our community's knowledges are so thoroughly shaped by the visual media. Not very long ago a young Black woman clerk appeared quite excited that I was shopping at her store. "Aren't you the woman on 'A Different World?" "So, when I told the young woman my name, she said, "Oh, now I remember: the big afro!" I guess I am destined to go down in history as "The Big Afro." (Davis 422)

\section{W} ashington Post reporter Nathan McCall's 1994 autobiography Makes Me Wanna Holler: A Young Black Man in America is an interesting thread to pull when we try to unravel the disappearance of Black transformationist discourse in U.S. popular culture. It comes as no surprise that McCall's book is published by a major corporate house to New York Times bestseller status. The book fits easily into a couple of established mainstream categories for African American autobiography. By chronicling the details of his early life of racial hardship, criminality, drugs, and prison, McCall joins the tradition of literary realism that runs from Frederick Douglass to hip hop. And by structuring its story around McCall's metamorphosis from convict to solid citizen, the book echoes the conversion narratives in 1960s autobiographies such as Eldridge Cleaver's Soul on Ice and Malcolm X's Autobiography of Malcolm $X$. But unlike Cleaver and Malcolm X, the raising of McCall's consciousness does not lead to anything resembling revolutionary or transformationist thinking. Makes Me Wanna 
Holler's front cover and back flap photographs show the integrationist and nationalist poles available for mainstream representation in 1994. The cover features a scowling McCall, sporting a gold chain and a vest in African colors, seated in front of a graffiti-covered wall. This conflation of drug-dealing gangster and militant nationalist easily fits the six o'clock news image of a young black male, one of the images that drives a multi-million dollar fashion and entertainment industry based on white middle America's fears and fascination. ${ }^{4}$ The picture on the back flap shows our civil rights fantasy: a smiling McCall in dress shirt and tie, seated in front of his keyboard in his Post cubicle.

Between these covers, McCall bears witness to black rage, describes his personal odyssey, and decries "black-on-black violence" and the wasted potential in so many black youth gone wrong. His anger, articulated in an engaging style that is partstreet and part-Post journalistic realism, gives the illusion that McCall represents a threat to the system he has infiltrated. But the overall assimilationist stance of the book, represented in what Jill Nelson calls McCall's "casual misogyny," and McCall's relative blindness to and complicity with the various forms of systematic oppression that fall outside of the racism that affects him personally leave Makes Me Wanna Holler a long way from any kind of transformationist politics. The insight that McCall gains from his experience always comes back to the traditional liberal platitudes we have come to expect from The Washington Post and Random House:

I have come to believe two things that might seem contradictory: Some of our worst childhood fears were true-the establishment is teeming with racism. Yet I also believe whites are as befuddled about race as we are, and they're as scared of us as we are of them. Many of them are seeking solutions, just like us. (402)

The political contours of Makes Me Wanna Holler are not that much different from those of the dozens of other African American autobiographies published by mainstream presses in the 1990s. McCall may occupy a different rhetorical space than Oprah Winfrey or Colin Powell, but he is not out of place on the same book shelf. But Makes Me Wanna Holler does deserve some attention in the chronicle of recent African American political history. Nathan McCall was coming to consciousness as Black transformationist politics was disappearing from the U.S. mainstream radar screen, and his book contains an interesting embedded narrative of that disappearance.

McCall was seventeen years old in 1972, when it seemed to him that the "lyrics from Curtis Mayfield's album Superfly were blasting from every radio and sound system in black America" (98). Mayfield's album is the soundtrack to the movie Superfly, a central text in Makes Me Wanna Holler. As 1960s Black Power transformationist politics is gasping its last breaths, McCall has Curtis Mayfield's falsetto ringing in his ears, and he watches Black Power disintegrate in a rush of swiftly changing style, while trying hard to emulate Youngblood Priest, the hero of Superfly:
Almost overnight, brothers shifted from Black Power chic to gangster buf- foon. Suddenly, cats who had been sporting dashikis and monster Afros broke out the platform shoes and crushed velvet outfits that made them look like clownish imitations of the flamboyant Priest. (100)

The political and economic shifts beneath these fashion choices have become virtually invisible to McCall. The young black men who just a few 
years earlier would have seen the Black Panthers, the most explicitly transformationist 1960s black dissident group, as the most viable response to racist capitalism now recognize only capitalist alternatives as the way to beat The Man. McCall and his friends see the "new consciousness" and "Blood" and "Brotherman" rhetoric of a previous generation of "dudes coming home from the Vietnam War" as anachronistic and ineffectual. This dismissal of Black Power politics is starkly dramatized in a pivotal scene in Superfly. Three men listed in the credits as "militants" and dressed in the turtlenecks and berets that McCall would call "Black Power chic" confront Priest about his drug dealing in their neighborhood. He stares them down and tells them that their efforts have done nothing for the community. As soon as they get some guns, he says, and start really fighting back against whitey, he'll be right there with them. Until then, they'd best leave him to his business. As they leave with their tails between their legs, the "militants" have not only bowed to Priest's superior masculinity, they have also relinquished any claims on effective resistance. At almost the exact moment that the state police apparatus is mopping up in its war against the Black Panthers, ${ }^{6}$ one of the most popular movies in the U.S. is showing a drug dealer giving Black Power the bum's rush.

With the synapses between the FBI base and Superfly superstructure firing so well, black transformationist politics has been pushed out of the frame. The only alternative to integrationism McCall can see is ghetto entrepreneurship. To his way of thinking, selling drugs was

no more far-fetched than the civil rights notion that white people would welcome us into their system with open arms if we begged and prayed and marched enough. As for the risks, dealing drugs seemed no more risky than working a thankless job at the shipyard for thirty years, always under the fear of being laid off. It was six of one and half a dozen of the other. (99)
In McCall's rock and a hard place universe, civil rights begging gives no access to the white system, but at the same time there is no systematic economic alternative to the thankless job at the shipyard. This binary choice is the same one that drives Superfly. Early in the film, Priest's sidekick Eddie, his finger squarely on the pulse of the early '70s pincers closing on black American political dissent, describes the cocaine trade as the only workable and profitable space "The Man" has left for black people. When Priest talks of getting out of the life, Eddie laughs at him, deriding his ability to go shipyard straight and give up the expensive clothes, cars, and women that come with dealing drugs. The film allows Priest and Eddie only two choices, between drug dealing or poverty and victimization, between working the system or getting crushed by it. For McCall, the choices are virtually the same. The only narrative with any possibility for success is the one in which McCall, like Priest, beats the white man at his own game.

In Superfly, the moment when Priest frees himself from his white masters and achieves complete selfdetermination is also the moment that shows how Priest's ultimate victory is ultimately inscribed in the system he beats. Priest outsmarts the corrupt policeman who is trying to prevent his getting out of the drug business, but he does so without disrupting the prevailing system. He may play the game a little too well for members of the establishment, but he does nothing to change the rules. Priest tells the cop that he is going to walk away unscathed because he has used his drug money to purchase a contract. If anything happens to Priest the cop and his family will all be killed. Both the cop and the audience know that Priest means business when he drives his point home by telling the cop that this is no idle threat, that he isn't trading in any of "that old-time nigger shit."

Closeup on Priest telling The Man that he has hired "the best killers ... white 
killers," then cut to a longshot of Priest walking away triumphant, having outManned The Man. Trade the purple pimp coat for a mask or a cape and he could be The Lone Ranger or Batman.

The same sort of solitary Emersonian self-reliance underwrites McCall's journey to mainstream respectability. There is no sense of community or solidarity in his understanding of his predicament:

When I read about shootings in urban areas and at home, I often flash back to scenes in which I played a part. It's hard for me now to believe I was once very much a part of that world, and harder still sometimes for me to adapt to the one I crossed over into. My new life is still a struggle, harsher in some ways than the one I left. At times I feel suspended in a kind of netherworld, belonging fully neither to the streets nor to the establishment. (402)

It is not hard to imagine Youngblood Priest moving into the same liminal space at the end of Superfly. Certainly both Priest's and McCall's system-beating maneuvers are grounded in the same sort of insider knowledge. Priest learns police tactics and McCall learns to write. McCall's road to the Post newsroom has many of the same turns as Priest's road out of the ghetto drug business. The legal economy shuts him out, he turns to drug dealing, this sends him to prison, where, ironically enough, he gains access to the educational system that gives him the tools to write himself into the legal economy. Makes Me Wanna Holler's story may, as Henry Louis Gates, Jr., tells us (in a back cover blurb), lean on "such predecessors as Richard Wright's Black Boy and Claude Brown's Manchild in the Promised Land," but its basic structure is right out of Superfly.

Looking back over the twenty-two years between the release of Superfly and the publication of Makes Me Wanna Holler, McCall sees Superfly as a milestone in the history of black resistance:

Almost instantly, Priest became a cult figure for brothers everywhere. Here was a film that gave us something rare in movies-a black hero-and expressed the frustrations of a lot of young brothers, who were so fed up with the white man that they were willing to risk prison, and even death, to get away from him. Perhaps for the first time in this country's history, young blacks were searching on a large scale for alternatives to the white mainstream. One option, glamorized by Superfly, was the drug trade, the black urban answer to capitalism. (9899)

This passage is both a testament to the institutional suppression of African American history and the extent of McCall's assimilation by the time he sits down to write Makes Me Wanna Holler. Transformationist dissent has been so effectively erased that McCall is able to see 1972 as "the first time . . young blacks were searching ... for alternatives," missing hefty portions of both the immediately preceding decade and three centuries of black struggle. Economic boundaries have become so constricted that he reads Superfly as the "answer" to capitalism, rather than the capitulation it actually is.

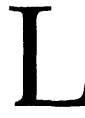
ooking back through the twenty years of hegemony that conditions McCall's memory, we see that Superfly is not the only black box office success in the early Seventies. Between 1970 and 1972 more than fifty feature films were made with black audiences in mind, most of which we now lump under the heading "blaxploitation," a genre characterized by low production values, cops and criminals action, funky soundtracks, and big doses of sex that emphasize macho stud constructions of black masculinity. The unexpected success of Shaft and especially Melvin Van Peebles' independent film Sweet Sweetback's BaadasssssSong alerted Hollywood to the profit potential in blaxploitation. Sweetback, usually pegged as the original blaxploitation film, cost $\$ 500,000$ to make and took in over $\$ 10$ million. This led the studios to turn away from 
such fare as To Sir, With Love and Guess Who's Coming to Dinner and toward the blaxploitation formula to boost black box office. Superfly, The Mack, Black Caesar, Cleopatra Jones, and dozens of others cashed in on the new post-Sixties version of black empowerment. When groups such as the NAACP, CORE, and the SCLC objected to the film industry's cynical exploitation of stereotypical black sex, violence, and misogyny, Hollywood executives pointed to box office receipts and claimed that they were only giving black audiences "what they wanted."

The studio blaxploitation pictures were popular with black audiences, but it is a stretch to suggest that they represented what African Americans wanted. As McCall points out, movies of any kind with black heroes were rare in 1972. Unlike the situation in the U.S. popular music industry, African Americans had played little or no role in the deployment and control of black images in U.S. film. In the 1970s, there was no cinema equivalent of Motown or the long tradition of U.S. Jazz. The Seventies blaxploitation explosion is roughly equivalent to the early part of the century when white record companies began to record and market "race" records. The means of production and distribution were (and still are) so completely in white hands that, while aspects of the result may have appealed to black consumers, we can also be pretty sure that the notion of "what they wanted" came to us heavily mediated. This mediation arcs across the relationship between Van Peebles's Sweetback and the studio blaxploitation pictures. As Manthia Diawara has pointed out, Black independent cinema, from Oscar Micheaux through Van Peebles to Spike Lee, has generated the "themes and narrative forms" that "mainstream cinema constantly feeds on" (4). Hollywood blaxploitation feeds heavily on the juiciest pieces of Sweetback, but, as with most mainstream appropriations of black culture, it leaves the undigestable revolution- ary morsels behind.

After a series of frustrating experiences with major studios, Van Peebles chose to write, direct, star in, produce, score, and arrange for the distribution of his story of a sex performer's evolution into a black militant. Sweetback is significant not only for its status as a blaxploitation originator and its blackcontrolled production, but also for its use of Black Power ideology. In a 1971 interview, Van Peebles consciously opposed his work to Shaft in explicitly Marxist terms: "Black films should deal with images of our position in the superstructure. They should all work toward the decolonization of black minds and the reclaiming of black spirit" (Murray 165). Huey Newton, in a laudatory review in the Black Panther newspaper, echoed these sentiments, saying that Van Peebles "has certainly made effective use of one of the most popular forms of communication ... in revolutionary terms" (qtd. in Murray 77).

While Sweetback does contain the regressive sex, violence, and misogyny that would come to characterize future blaxploitation films, it also has progressive doses of solidarity and consciousness raising that set it apart from its successors. The plot turns on Sweetback eschewing his identity as a cynical sex show stud who goes along to get along with the police. After standing idly by while two cops beat a black revolutionary, Sweetback is suddenly galvanized into action, turning and beating the cops and rescuing the revolutionary. This leads to an extended chase, where we see a variety of instances of police brutality directed against black people intercut with scenes of Sweetback coming to understand his former exploitation and colonization. The film ends with Sweetback, like Youngblood Priest, having outwitted white power, but not simply for personal economic gain and material comfort. Sweetback's opening credits list "The Black Community" as its primary star, and throughout the movie we see working and underclass 
blacks providing solace and aid to Sweetback as he runs from the cops. This kind of solidarity stands in stark opposition to the lone-wolf maneuvers of Priest, whose moment of comfort and rest comes with his white mistress in a penthouse apartment high above the ghetto.

The black male cool and machismo as defined by Sweetback would become the commodity that Hollywood packaged in blaxploitation films like Superfly, with Van Peebles' independent revolutionary intent left behind. At the same time, the flood of studio blaxploitation pictures and Hollywood's block-booking system effectively jammed distribution channels, making independent visions like Van Peebles' virtually inaccessible. It would be difficult to predict how revolutionary black cinema would have progressed had it not been coopted and absorbed by corporate Hollywood, just as it is difficult to know what would have happened to the Black Panthers had they not been so explicitly targeted by the state police apparatus. Both Sweetback and the Panthers showed some counterrevolutionary tendencies, especially in their attitudes about women. But no matter how things would have evolved, we can be sure of the similarities in the way things turned out. Just as the Panthers were pushed by state violence into Cripdom, black film became ineluctably linked to drug-dealing gangsterhood as it became corporate blaxploitation.

It is significant that, from a host of blaxploitation movies, McCall chooses Superfly as the film that best represents his generation. (Spike Lee has done the same thing, identifying Sweetback as the only blaxploitation film that influenced him and yet choosing to teach Superfly in his African American film class at Harvard.) The equally popular Shaft and many other blaxploitation films feature black policemen or James Bond-type characters as their heroes. But for McCall, Youngblood Priest the cocaine hustler more realistically repre- sents possibility:

Superfly influenced the style, thinking, and choices that a lot of young black men began making around that time. I know it deeply affected me. I came out of that movie more convinced than ever that the white man and I were like oil and water: We didn't mix. My partner Shell Shock was on the same wavelength. He started thinking that maybe there was a future in dealing drugs. A few weeks after we saw the movie, we were sitting around at his place getting wasted when Shell Shock outlined his game plan, which was essentially a scaled-down version of the plan Priest had devised in the movie. "I know I can do it, man. Most of the white folks that got money did something illegal to get it. Look at how the Kennedys got started. They bootlegged liquor during the depression, then went legit. Now they millionaires! All I gotta do is make enough money to start my own business, then I can quit the drug game."

It was shortsighted, far-fetched fantasy for sure. (99)

This passage is a capsule summary of the black political possibilities represented in U.S. popular culture in the post-Superfly years. McCall comes out of the theatre with a separatist sentiment aroused, looking for ways to dress right and dodge the white system. That younger version of McCall sees Priest as a role model, while the older, more "mature" McCall recognizes him as an outlaw. Mature McCall shows us he hasn't lost touch with his blackness, hasn't gone the way of Uncle Clarence Thomas, by continuing to acknowledge Superfly's seductive edge and refusing to lapse into a moralizing sermon about drugs and the devil. But he also reinforces the same binary choice between gangster and citizen built upon essentialist conceptions of race and drugs that recurs again and again in the autobiographies, talk shows, movies, music, and wars on drugs that would fill the Eighties and Nineties. Young McCall's buddy Shell Shock not only sees Priest as a role model but also recognizes the analogy to more "mainstream" forms of criminal activity. This insight into the dynamics of power in the U.S. 
political system is dismissed by mature McCall as "far-fetched fantasy for sure." Like Priest and the Bloods and Crips after the police destruction of Black Power, McCall pragmatically acquiesces to the idea that his choices no longer include transformationist politics. He has so completely succumbed to the ideology of personal choice that he can hear larger structural or class analysis only as far-fetched fantasy. Again, this is not surprising, given that McCall writes from a mainstream position for a mainstream audience. In the last twenty-five years, black transformationist dissent has virtually disappeared from any popular culture that passes through corporate hands. And on those rare occasions that something resembling transformationist critique does slip through, it is quickly contextualized as ridiculous and unrealistic.

\section{$\mathrm{T}$} he career of Spike Lee, especially the reception of his movie Do the Right Thing, provides a paradigmatic example of the fate of African

American transformationist politics in mainstream representations. After the heyday of blaxploitation, the next significant eruption of blackness into mainstream U.S. film would come with the arrrival of Lee in the late 1980s. (As Melvin Van Peebles points out, "In the years after Sweetback, there were less than twenty films actually controlled by African Americans" [7]). The success of his independently made first film She's Gotta Have It led to his emergence as a bankable Hollywood director, and cleared the ground for such films as Boyz $N$ the Hood, New Jack City, Straight Out of Brooklyn, and Juice. ${ }^{7}$ Lee has worn his status both flamboyantly and uneasily through a series of feature films, including School Daze, Do the Right Thing, Mo' Better Blues, Jungle Fever, and Malcolm X. Of these movies, Do the Right Thing is easily the most original and controversial, provoking a plethora of vigorous reactions from all points on the political compass.

Given his body of work and his deep engagement with Madison Avenue, it would be a stretch to describe Spike Lee as anything like a revolutionary. Amiri Baraka is only exaggerating a bit when he calls Lee "the quintessential buppie, almost the spirit of the young, upwardly mobile, Black, petit bourgeois professional" (146). But, unlike any of his other films, Do the Right Thing shows a solid transformationist underpinning. ${ }^{8}$ The story follows a variety of characters through a hot summer day in the life of the Bedford-Stuyvesant neighborhood in Brooklyn. From the beginning, it works against our realist expectations-creating broad types rather than round characters; painting the screen in overly bright, almost garish colors; showing political murals and slogans (such as the Liberian flag and "Tawana Told the Truth") in the background; and staging several choral moments with actors speaking directly to the camera. The film's central location is Sal's Famous Pizzeria, owned and operated by Sal, an Italian American, and his two sons Pino and Vito, who commute into Bed-Stuy each day. The plot is engendered in the morning when Buggin Out, one of the neighborhood's residents, demands that Sal include some pictures of black people on his Pizzeria's "Wall of Fame," currently filled with autographed pictures of white Italian American celebrities. In response, Sal invokes the classic U.S. liberal bourgeois notion of property rights, telling Buggin Out that, as long as the pizzeria is Sal's, the wall will be covered with "American Italians" and that as soon as Buggin Out owns his own pizzeria he can put as many "brothers" as he wants on the wall. Buggin Out, occupying a more populist position, reminds Sal that the black people in the neighborhood spend "much money" on his pizza and thus are entitled to some rights in his establishment. An altercation is avoided when Mookie, Sal's delivery man 
(played by Lee), hustles Buggin Out through the door, reminding him that such agitation could endanger Mookie's job.

This stew of economic imperialism, ethnic solidarity, and labor relations bubbles throughout the day, as we watch Buggin Out try to organize a boycott of Sal's, Mookie try to balance his job with his responsibilities to his girlfriend and son, and Sal try to keep a lid on his older son's seething racial anger. The movie snaps with the intelligence, pace, and humor for which Lee has been rightly praised, and by closing time, as Sal counts the till, both he and the audience have had "a really good day." Were it to end at this point, with Sal telling Vito and Pino that the pizzeria will someday be Sal and Sons, and promising Mookie that there will always be a delivery boy job for him at Sal's, Do the Right Thing would no doubt have been the feel good hit of the summer. We have been treated to an hour and a half of colorful ethnic people doing colorful and relatively unthreatening ethnic things. If the music swells (some melancholy jazz, please, no Public Enemy) and the credits roll here, then critics probably end up comparing the movie favorably to other ethnic romances like Moonstruck. 9

But instead Sal opens the door to make four last slices for some local teenagers ("They love my food," he says). Buggin Out and Radio Raheem (the biggest guy on the block with the biggest boom box) follow them in, blasting "Fight the Power" and shouting their demand for pictures of black people on the wall. Sal smashes Radio Raheem's box with his baseball bat, and the ensuing fight spills out into the street and draws the cops, who end up killing Radio Raheem in a choke hold. As an ominous crowd gathers around Sal and sons, Mookie tosses a garbage can through Sal's window, which leads to a riot and the eventual burning of the pizzeria. This violent ending (along with two quotes about violence from Martin Luther King, Jr., and Malcolm X that immediately precede the final credits) would result in the spillage of gallons of critical ink across hundreds of pages of newspapers, magazines, and academic journals, much of which revolves around questions of responsibility and motivation: Is Buggin Out a political activist or just a b-boy with too much time on his hands? Is Sal justified in breaking Radio Raheem's tape player? When Mookie throws the garbage can through the window is it an act of heroism or vandalism? What is Spike Lee trying to say by following a Martin Luther King, Jr., quote about non-violence with a Malcolm X quote claiming that violence in self-defense is justified?

One interesting exchange of this sort takes place between W. J. T. Mitchell and Jerome Christensen in Critical Inquiry. Mitchell calls Mookie's garbage can toss "an ethical intervention," and goes on to tell us that "at the moment of Mookie's decision the mob is wavering between attacking the pizzeria and assaulting its ItalianAmerican owners. Mookie's act directs the violence away from persons and toward property, the only choice available in that moment. Mookie 'does the right thing,' saving human lives by sacrificing property" (897-98). But

Christensen questions both Mitchell's reading of the scene and the ethics of Mookie's action:

There are cries of "They did it again, just like Michael Stewart, Eleanor Bumpers" (vicitims, like Radio Raheem, of police violence), but you can run the tape backwards and forwards, fast or slow, and you will not hear a single threat of physical violence against the American Italians. When Mookie makes his decision (he wipes his eyes as if stripping away delusion), he is partially framed by a background figure (by appearances a Latin) who is standing casually with hand clasping wrist. When Mookie picks up the garbage can and begins his approach he passes in front of a cluster of curious black onlookers (are they a mob? part of a mob? moblike?) who stand in casual poses with arms crossed. It is only when Mookie accelerates toward the window that the uni- 
fying motion ripples through the assembly; Mookie's act galvanizes the group; violently he provokes a violence that, because it has no claim to "self-defense," should be called, according to Malcolm X's criterion, not intelligent but stupid. (585)

Mitchell and Christensen obviously hold very different views regarding Mookie's intentions, but they both read the scene through the same lens. At stake for them is Mookie's individual character and the specific consequences of his act, understood in a traditionally liberal, ethical context that demands that we read the pizzeria incident as though it were taking place in the suburbs. As Christensen puts it, "ethical judgment entails respecting cases" (584).

But for Spike Lee, the context is very different: "So many times white people have said to me: 'Oh, Spike, why did Mookie throw the garbage can through the window of Sal's?' But I've never, ever had a Black person, an African American, ask me that question. Not ever, it's understood" (By Any Means 4-5). Lee's division of his audience into a (white) class that can't understand the garbage can scene and a (black) class that easily understands it suggests that we are to see the scene as typical rather than exceptional, as one case among many similar cases rather than as a unique situation with its own ethical contours. In this context, it makes no difference what Mookie's specific motivation is as he hurls the garbage can, or whether Mitchell or Christensen is reading it right. Mookie's anger and frustration extend well beyond the moment and connect with systematic forces that, according to Lee, all African Americans understand, the same way that the crowd in front of Sal's sees the death of Radio Raheem as coming from the same place as the deaths of Michael Stewart and Eleanor Bumpers. If Mookie chooses not to throw the garbage can, the conditions that could lead to the burning of Sal's or any number of other violent eruptions have in no way been changed. If Mookie doesn't throw the garbage can, someone else will. If no one throws a garbage can, some other violent cauldron will bubble over.

Given the rest of the movie, this is the most obvious reading of the scene. Do the Right Thing is an excellent portrayal of the dignity and humor of ghetto life, but it also pulses with the tension and potential violence that come with economic exploitation and abandonment. Sal begins the day complaining about the heat and saying that he feels "like I'm gonna kill somebody." This sets the tone for a day of confrontations: between Sal and Buggin Out, Pino and Mookie, Radio Raheem and a group of Hispanic teenagers with a stereo almost as big as his, Radio Raheem and a Korean grocer, Da Mayor and the Korean grocer, Buggin Out and a white guy in a Celtics jersey who scuffs Buggin Out's clean Nikes, Mookie and his girlfriend Tina, Pino and the mentally handicapped Smiley, the cops and the kids who open a fire hydrant, Sal and Mookie over the way Sal looks at Mookie's sister. These flashpoints are so consistent, punctuating the film like a second sound track, that it is difficult to understand them in terms of individual psychology or imagine them happening in a neighborhood with more wealth, space, air conditioning, and economic opportunity. Lee deploys his incidents in a way that demands that we ask questions about the social and economic forces of Wall Street and Gracie Mansion that have helped shape this block in Brooklyn.

So once the violence does erupt at the end of the movie, we have to understand it according to the same criteria. Radio Raheem's death and the burning of Sal's are inevitable banalities, not tragic accidents that could have been avoided if only certain individuals had made better choices. No matter how hard the characters try to do the right thing they cannot overcome the centuries of wrong things that have been done to them. This reading accounts for Lee's refusal to 
finger any single character or cluster of characters as directly responsible for what happens. Sal and Mookie are the most sympathetic characters in the film, Buggin Out has a point about the Wall of Fame, and Radio Raheem shouldn't have to die just because he plays his music too loud. We have even seen the police earlier in the film as having a grudging respect for the neighborhood residents (taking their side against a rich white guy in a convertible), and the cop who strangles Radio Raheem is portrayed as a frightened young man whose adrenalin gets the best of him. Lacking a convenient villain, and unless we want to resort to the standard mainstream idiocy of describing the violence as "random" or "unmotivated," we must look for explanations in the larger forces of colonization and economic imperialism.

In many of his discussions of Do the Right Thing, Lee makes it clear that he wants us to see the film in these larger terms. In his production journal, Lee writes that the movie is about the

\begin{abstract}
black underclass in Bed-Stuy, a community that has some of the highest unemployment, infant mortality, and drug related homicides in New York City. We're talking about people who live in the bowels of the social-economic system, but still live with dignity and humor. (qtd. in Morrison 25)
\end{abstract}

In various interviews, Lee also shows that he understands the long history of black oppression and the difficulty of conveying the effects of that oppression to an affluent white audience:

I don't think [white people] should be scared. I have sympathy for them if they have strong emotions about this film. But if white people look at this film and feel uncomfortable for 15 minutes, I think that's going to be good-because they have no idea how black Americans have lived for 400 years! If they have to feel uncomfortable for 15 minutes, then that's all right. The movie's going to be over, and they'll go back to wherever they live [while] black people still make up the large permanent underclass. (Sterritt 7)

Again, the point here is not to paint
Spike Lee as a consistent purveyor of radical politics. It is to show that $D o$ the Right Thing, both in its intent and its execution, has a political kinship with Sweet Sweetback's

BaadasssssSong and is an intelligent articulation of the conditions that should lead to a transformationist politics. That it is a movie with transformationist possibilities becomes clear with even a cursory glance at its critical reception. Do the Right Thing may have struck the same nerve with the corporate press that the Black Panthers struck with J. Edgar Hoover, ${ }^{10}$ but by 1989 transformationist analysis had become so scarce and unintelligible in the mainstream public sphere that it almost never appeared in the many discussions surrounding Do the Right Thing. Lee's own discourse tends to veer pretty quickly from economics to a quasi-essentialist notion of race. And the rest of the mainstream arguments about Do the Right Thing, both positive and negative, consistently organize themselves around questions of violence, aesthetics, and drugs.

Do the Right Thing has the distinction of being the film that inaugurated the now familiar panic about black movies as incitement to violence. In the same way that blaxploitation films were blamed for drug use, Do the Right Thing and many of the black films that were greenlighted in its wake (such as Juice, New Jack City, and Boyz $N$ the Hood) have been portrayed as potential catalysts for riots. Joe Klein, writing in New York magazine, had this to say about Do the Right Thing: "If Lee does hook large black audiences, there's a good chance the message they take from the film will increase racial tensions in the city. If they react violently-which can't be ruled out..." (14). Arguments such as this are some of the most pathetic and racist attempts to look beyond the economic oppression that leads to innercity violence. ${ }^{11}$ Lee offers the obvious response to critics like Klein in an interview with Michael T. Kaufman:

\footnotetext{
"The only thing that really hurts are
} 
those articles that are saying that 'Do the Right Thing' is going to cause riots. 'Do the Right Thing' was not showing the week of the Superbowl in Liberty City," he said, citing the Miami neighborhood where rioting erupted last winter. "To my knowledge, what happened there was that a cop killed a black kid on a motorcycle who supposedly had robbed someone. That's what started the riot. Better talk about the conditions that make things like that happen." (H1)

But the mainstream press was intent on taking seriously the idea that Do the Right Thing could, by itself, constitute one of those conditions. The New York Times, for example, "staged an instant symposium of experts on ethnicity and urban violence" (Mitchell 891). In this discussion, even those who supported the film accepted the notion of Do the Right Thing as a potential powder keg. Henry Louis Gates, Jr., offered this defense:

\begin{abstract}
I want to address the question of the incendiary nature of the film. I think that is the importance of the ambiguity-not only at the end, but throughout. He could have made a coercive movie that would show only one side of all the larger questions here, but he didn't. This is a porous movie, this is a movie about choices. The moviegoer is even left with a choice, put there literally through the two quotes of Malcolm X and Martin Luther King. That's why it's not, I think, incendiary. It allows you to bring choice and interpretation to it. And that's what I think will keep it from causing social problems in the hot summer. (New York Times 1)
\end{abstract}

Although Gates feels that Do the Right Thing is not incendiary, he still allows for the possibility that a movie could cause "social problems in the hot summer." Thus the terms for the debate are tightly drawn. We may disagree about whether or not Do the Right Thing will spark riots, but we must always understand that it could. Rather than rejecting such terms, like that "radical" and potentially irresponsible young filmmaker Spike Lee, we should take the view of his sympathetic but more "reasonable" critics like Gates. And we are left to make judgments about the kind of questions Mitchell and Christensen debate: Did Mookie do the right thing? Is Sal a racist at heart? Will that Malcolm X quote lead volatile black people to torch theatres across America? As long as this is the focus of the discussion, serious consideration of the conditions that create the consequences we see at the end of Do the Right Thing will never take place.

A more subtle but equally effective way to divert transformationist discussion of the film is to critique it on the basis of aesthetics. In this effort, mainstream reviewers can employ a received formalist vocabulary of "art" that has trickled down from academia as the dominant critical discourse in the U.S. in the twentieth century. Juan Williams, for example, in a Washington Post review titled "Why Spike Lee's New Film Ultimately Fails," finds Lee guilty of "an artistic copout" (G1). The same ambiguity and open-endedness that Gates celebrates leads Williams to see the film as hopelessly muddled and confused. Leaning heavily on the New Critical value of closure, Williams claims that Lee "forgets about his responsibility as an artist to say something-to take his story toward a significant end that transcends the details and offers a vision" (G9). This lack of responsibility is embodied in what Williams sees as Lee's four failed attempts to bring $D o$ the Right Thing to a satisfactory ending. The closing of Sal's Pizzeria, the fight between Sal and Radio Raheem that precipitates the riot, and the morning-after scene between Sal and Mookie are all false starts toward the ultimate failure of the quotations from Martin Luther King and Malcolm X that finally do end the film. Here Lee not only fails to finish to Williams's satisfaction, he also sins against generic coherence as he "abandons his medium-film-and tries prose." This analysis allows Williams to deliver his final judgment on Spike Lee: "With his flawed attempts at an ending he has slipped from artist to propagandist" (G9). In Williams's unexamined for- 
malist world, this slip is a cardinal sin for the "artist." And the accusation itself effectively forecloses any conversation about those subjects that fall under the heading of "propaganda." Unlike cruder critics who rave about violence and other social consequences outside the magic circle of the artifact, Williams the aesthete finds the film unfaithful to the pure terms of art.

This same familiar set of assumptions lies behind the review of Do the Right Thing in The New Yorker, the magazine to which most good liberals look for the final word on the current cinema. In "Open and Shut," Terrence Rafferty offers an even-handed, purring refinement of the aesthetic dismissal:

In form, "Do the Right Thing" is a multi-character, portrait-of-a-community movie. When this sort of picture is done skillfully, it can be exhilarating: Renoir's "The Crime of Monsieur Lange," Altman's "McCabe and Mrs. Miller," and Scorcese's "Mean Streets" come to mind. The pleasure of community movies is their open-endedness, the (relative) freedom they allow us to observe the particulars of relationships in small, self-contained social units; they seem unusually responsive to the ambiguity and variety of experience. For long stretches, Lee's movie is enjoyable in this way. Characters are introduced, and while we wait to find out what they'll have to do with each other we can take in an abundance of atmospheric details-the lack of airconditioning in the apartments, the way the sunlight looks sort of hopeful at the beginning of the day and then turns mean, the street wardrobe of $\mathrm{T}$ shirts, bicycle shorts, and pristine Nikes-and listen to the casual speech of the neighborhood's residents, learn to hear in its varied rhythms how people who have lived too close for too long express their irritation and their affection. As we get our bearings, the movie has an easy colloquial vivacity, and a sensational look. The superb cinematographer Ernest Dickerson (who has worked on all Lee's movies) gives the images a daring, Hawaiian-shirt glare: if the light were just a touch brighter, the colors a shade bolder, we'd have to turn away, but Dickerson somehow makes these clashing sensations seem harmonious. Lee's script seems to be trying to do something similar, but, despite its ingenuity, it doesn't succeed. As the long, sticky day goes on and the exchanges between the characters get edgier, nastier, more elaborately insulting, we begin to feel something ominous creeping in, which at the time we may take to be our realization that racial violence is inevitable, but which later on we may identify as our intuition of a different kind of disharmony-the jarring incongruity of Lee's "open" manner and his open-and-shut argument. (79)

Rafferty sets the standards for formal judgment by putting Lee in a tradition of white filmmakers who make similar collage movies-showing us that deep down all communities are the same, that a slice of any life will resonate with any other. He goes on to praise the movie's easy use of this form, the way it draws its disparate elements toward harmony. But as soon as we begin to be drawn to the "realization that racial violence is inevitable," Rafferty pulls us back, making sure that we know that our heightened response is not due to the representation of a social inevitability, but just an artistic mistake on Lee's part.

Several times Rafferty invokes Martin Scorcese to let us know that he isn't squeamish about violence, but he is careful to make sure that we recognize the proper sources of violence:
[Lee's] model is clearly the Scorcese of "Mean Streets" and "Taxi Driver," but in Scorcese's films the final bursts of violence are generated entirely from within, from the complex internal dynamics of the communities and indi- viduals we've been watching. Lee's cli- max only seems to have that sort of terrible inevitability. In order to believe it and to find the characters' behavior in these disturbing scenes wholly comprehensible, we have to accept a proposition that's external to the terms of the movie, an abstract notion of the kind that no movie can truly demonstrate: that we're all bigots under the skin. (80)

Proper movie violence is always the product of individual psychology or "internal" community pathology. If we need a "proposition that's external" to understand either the violence or the 
community, then we're watching a movie that's neither whole nor comprehensible. And if we insist on paying attention to these externals, Rafferty makes sure to draw us to the wrong one: the "abstract notion" of individual racial bigotry rather than the systematic creation and perpetuation of a permanent underclass that drives the events in the movie. When he does talk about the economic source of the riot, Rafferty is dismissive, telling us that "lashing out at Sal because he's white and owns a business and is therefore a representative of the racist power structure ... is a woefully imprecise image of fighting the power" (80). Riots do tend to be woefully imprecise, but they are generally not random or unmotivated.

Perhaps Rafferty feels that it would be more consistent with the internal dynamics of the community if Buggin Out and Radio Raheem were to lead the crowd across the Brooklyn Bridge and down to Wall Street to fight the real power. This desire for a surrealistic but more precise ending would be pretty ironic, given the critical hue and cry about Lee's choice to leave drugs out of Do the Right Thing. From the right and the left, from The National Review to the Village Voice, reviewers found Lee guilty of violating the law of verisimilitude by not littering his film with illegal drugs. They feel that no black community can be properly represented without a crack dealer on every corner, a junkie on every stoop. In the Voice, Stanley Crouch complains that when no "villains such as drug dealers appear" Lee "creates a fantasy Bed-Stuy neighborhood" (qtd. in Morrison 25). Lee, recognizing the racism in this criticism, responds that the same magazines that describe drugs as a problem infecting all areas of society never "ask the people who made 'Rain Man' or 'Wall Street' why they did not include drugs in their pictures" (Kaufman H20). Drugs and African Americans have become so inextricably linked in the popular imagination that this obvious question does not even occur to most reviewers. Superfly probably didn't seduce black America with its depiction of the drug life, but along with other blaxploitation films and a barrage of mainstream popular representations, it did help convince white America that "the drug problem" almost always has a black face. Critics like Micah Morrison invariably bring a high-handed moralistic sensibility conditioned by blaxploitation to their negative reviews:

\begin{abstract}
The omission of drugs is far from accidental. Wish them away, and the people become victims of outside forces entirely beyond their control-in a word, racism. As Spike Lee sees it, moreover, racism is embodied not just by brutal white cops but also by wellmeaning pizza-parlor owners. In the movie, the people are more threatened by pizza than by drugs. (Morrison 25)
\end{abstract}

Like Juan Williams and Terrence Rafferty, Morrison assumes a world in which people choose to be "victims," where disenfranchisement follows from drugs freely chosen, rather than the other way around. For him, there are no systematic connections across the inner-city landscape. Brutal cops, pizza, and drugs couldn't possibly flow into Bed-Stuy from the same "outside forces."

The cumulative effect of the critical reception of Do the Right Thing is a lot of smoke generated from a familiar and easily contained fire. From the pages of such institutions as The New York Times, The Washington Post, The New Yorker, the Village Voice, and The National Review, Spike Lee emerges as a righteously angry young black man. But the real insights of his best film, the insights probably most responsible for provoking so much charged commentary, are buried beneath a lot of harmless bluster. As long as it provokes only talk about black art inciting violence, or how close a black director gets to white aesthetic principles, or how no movie can possibly claim black authenticity without getting most of its characters high, Do the Right Thing, despite its obvious transformationist message, poses no 
threat to power.

Sadly enough, neither does Spike Lee after Do the Right Thing. None of Lee's subsequent films come anywhere near a radical political vision. It would, of course, be unfair to judge each of Spike Lee's films based on some sort of transformationist litmus test. Do the Right Thing is much more the exception than the rule among Lee's films in its concern with economic oppression. But a look at Lee's work in the wake of the controversy surrounding Do the Right Thing gives us some insight not only into Lee's individual vision but also into the way that the mainstream reception apparatus works to suppress transformationist dissent. Two "Spike Lee Joints" in particular, Malcolm X and Jungle Fever, are excellent examples of films that have been portrayed as transgressive but end up only reinforcing mainstream values.

$\mathrm{M}$ alcolm $X$ is the image that has most come to symbolize black opposition and resistance in the late twentieth century. While he was alive, mainstream representations of Malcolm X depicted him as a terrorist, the violent, frightening flip side of Martin Luther King, Jr. In death, the terrorist has been redeemed, turned into an icon and allowed to speak through texts like Alex Haley's The Autobiography of Malcolm X (a staple assignment in many high schools) and Lee's movie (which spawned the lucrative $X$ paraphenalia industry). Unlike Malcolm X's actual words in his later speeches (collected and published, but far less popular than the Haley book or the Lee film), these texts have little or no relationship to transformationist politics. The recent Malcolm explosion in print, film, and music has generally ignored the founding of the

Organization for Afro-American Unity, Malcolm's travels to visit revolutionary leaders in Africa, his offers of alliance with other progressive groups, and his repeated description of capitalism as "vulturistic." The events central to both Haley's book and Lee's film are Malcolm's break with Elijah Muhammad, ascribed to Muhammad's infidelities with Nation of Islam secretaries, and his trip to Mecca, where he learned that Islam is big enough for everybody. As both George Breitman and Manning Marable point out, a focus on personal differences with Elijah Muhammad and the spiritual uplift of Mecca erases the primary role of transformationist politics in the years leading up to Malcolm's death. ${ }^{12}$ Haley's book and Lee's film elide or erase Malcolm's trips to revolutionary Africa (trips that were much longer than his pilgrimage to Mecca) and meetings with leaders in newly independent countries. They leave out the years of growing tension between Malcolm and Muhammad over questions of political engagement (choosing instead to focus on the single "chickens coming home to roost" incident). And they minimize the long-term presence of the FBI in Malcolm's life (the feds don't appear in Lee's film until late in the last reel) and its significant role in his death.

Lee's focus on discrete, epiphanic events is an American storytelling tradition (Columbus discovered America, Lincoln freed the slaves, Brown vs. Board of Education desegregated our schools) that combines with the creation of an isolated, messianic personality to obscure the ongoing, but less dramatic, forces and patterns that lie beneath official history. As Marable points out, this sort of representation helps curtail social action:

Both Lee and Haley ignore the long history of African-American nationalism in the USA, preferring to see Malcolm as a "reaction" to white racism and prejudice, rather than as a product of a long and rich protest tradition.... The film-maker's goal was to create a cultural icon.... The creation of charismatic cultural Messiahs may be attractive to a middle-class artist like Lee, but it represents a political perspective grounded in conspiracy theories, social isolation, and theoretical confusion. If African-Americans 
conclude that only the genius of a Messiah can elevate the masses of oppressed people to the level of activism, no social protest is possible. (140-41)

The context in which Lee creates his Malcolm does not allow for this kind of activism and protest. In the interviews he gave around the production of his film, Lee describes the Autobiography of Malcolm $X$ not as a fulcrum for mass activism but rather as a bible for personal improvement:

\begin{abstract}
The main reason Malcolm $X$ told his story to Alex Haley was to put his life up there as an example for African Americans-or anybody, really-that you could change your life around if you really apply yourself. He says, "Look, people, I was a criminal. I peddled grass, I was a steerer, I was a criminal, I snorted cocaine. I got so depraved that even in prison I was called Satan." But he turned it around. (qtd. in Simpson 66)
\end{abstract}

Haley's book surely justifies this reading, and Lee's sympathy with the sensibility of the Autobiography leads to the fundamentally flawed ending of his movie.

The James Baldwin-Arnold Perl screenplay that Lee inherited was unfinished, and the ending of the story was left for Lee to write. Following Haley, he chose to emphasize Malcolm's 1964 hajj to Mecca and the now famous letter he wrote to his wife proclaiming this trip as having opened his eyes to the humanity of white people as the central events of the end of his life. Lee chose this ending despite having others explicitly offered to him. While he was researching the film, Lee spoke to W.E.B. Du Bois's son David, who was in Cairo with Malcolm. Along with describing the U.S. government surveillance that dogged Malcolm, Du Bois told Lee that Cairo and Accra were "near the high point of African liberation" during Malcolm's visit, and that "it was this mood of liberation that Malcolm attached himself to when he came to Africa" (By Any Means 39). Louis Farrakhan, when Lee interviewed him, was even more explicit in playing down the role of Malcolm's trip to Mecca: "The Malcolm I know was not impressed with rituals. You couldn't take Malcolm to Mecca and show him some blond-haired, blueeyed white man walking around a black stone and knock Malcolm out" (By Any Means 56). When Lee protests that "those letters weren't fabricated," Farrakhan reminds him that Malcolm had been to Mecca once before (in 1959) and talks about how "politically astute" Malcolm was. He goes on to tell Lee that the significance of Mecca's ghettoes and "white Arabs, throwing bread to Nubian women like they were feeding pigeons," would not have been lost on Malcolm (57). The letters, Farrakhan suggests, were part of Malcolm's strategy for creating alliances with civil rights leaders when he returned to the U.S.

The most cursory look at Malcolm's activities and speeches in 1964 and 1965 shows that the $\mathrm{Du}$ Bois/Farrakhan interpretation is much more faithful to Malcolm's last year than are Haley's and Lee's representations. For Marable, this is the result of class blindness:

I would suggest that the ideological
limitations of both Haley and Lee keep
their interpretations of Malcolm locat-
ed on safe, religious grounds rather
than on the more dangerous terrain of
race and class struggle. Haley was a
longtime Republican, and a twenty
year veteran of the U.S. Coast Guard.
Lee is primarily a product of the post-
civil-rights-era black middle class ....
(140)

It is important to recognize that the ideological limitations of Haley and Lee are also the ideological limitations of the society that celebrates their images of Malcolm X. Just as Du Bois and Farrakhan pointed Lee toward a transformationist Malcolm, Pathfinder Press, George Breitman, and Manning Marable have worked to make the politically radical side of Malcolm available to the larger society. Lee's deafness to Du Bois and Farrakhan is a product of the same pervasive ideology that cannot hear Pathfinder, Breitman, 
or Marable in the mainstream institutions that finance and make possible popular representations. We can see this in the way that the mainstream press reported the feud between Lee and Amiri Baraka over the making of Malcolm X. Baraka, a longtime Marxist/socialist and a consistent critic of Lee's films, felt that Lee's sensibility was far too middle class to do justice to Malcolm's legacy. His objections were very similar to Marable's, focusing on the way that the film did little to create useful images for real African

American resistance. The popular press, very comfortable with reporting prominent black people fighting with each other, described the dispute as being about Lee's portrayal of Malcolm's incarnation as Detroit Red, generational conflict, or the question of who speaks for black people-anything but ideology or class conflict.

In this atmosphere, it is easy to see the popularity of the Autobiography of Malcolm $X$ and the film Malcolm $X$ as flowing from their conformity to corporate ideology, rather than the individual visions of their creators. Had Haley and Lee chosen political visions farther to the left, their texts would surely have been marginalized, and the custodianship of Malcolm X's image would have been entrusted to someone else. But on a radar screen where Baraka shows up only as a cranky black nationalist foil for Spike Lee, and writers like Breitman and Marable don't even appear, Haley and Lee emerge as progressives, rather than the political conservatives that they are. The popularity of the Autobiography and the phenomenal success of Roots (both the book and the television miniseries) have established Haley in the public mind as a major voice for African American civil rights. Lee's own brash self-promotion and fiery rhetoric allow him to pass as a radical. In his book By Any Means Necessary: The Trials and Tribulations of the Making of Malcolm X..., Lee describes what he sees as his daring and dangerous battle with a white
Hollywood power structure over bringing his vision of Malcolm to the screen. The book makes it clear that Lee takes his responsibility to Malcolm's legacy seriously and that he was determined that control of the film remain in African American hands. And certainly Lee has been the victim of what he calls a "plantation" Hollywood system. But reading $B y$ Any Means Necessary it becomes clear that almost all of the battles between Lee and Warner Brothers were fought over money-how much of it the studio was going to make. The only thing about the film that threatened

Warner's executives was Lee's insistence that it run three hours. The Malcolm of Malcolm $X$ is the same Malcolm available in other forms of popular culture for oppositional purposes-personally engaging and rhetorically fierce, but not much of a threat to the real relations of power. Any doubts we may have had about this were erased a few years later when the film's ending set piece of a rainbow of children telling the camera "I am Malcolm X" became a television commercial with inner-city children using the same cadences to chant "I am Tiger Woods" in an effort to sell sporting goods for Nike, one of Lee's longstanding employers.

Between Do the Right Thing and Malcolm X, Lee made Jungle Fever, a film that predicts the politics of Malcolm X. Lee expected Jungle Fever to make even more noise than Do the Right Thing: "We had fireworks on Do the Right Thing, but I feel they are small compared to the fallout that will come after this new one. Do the Right Thing was about race and class, but Jungle Fever combines those two, plus sex, and this makes a much more combustible combination" (Five 16). The question of interracial sex did make a few critical waves, but compared to Do the Right Thing, Jungle Fever was just another movie. No one convened a special symposium, no one worried about riots. The reviews varied in their intelligence and sensitivity, but neither 
the overt nor the underlying premises of the film provoked the hysteria that Do the Right Thing did. Jungle Fever does deal with class, but in a way almost diametrically opposed to Do the Right Thing. The film's central relationship is between Flipper, a middle-class African American male architect, and Angie, a working-class Italian American temporary secretary. Beneath the focus on the problems of interracial romance, the film pushes us inexorably to see Flipper's affair with Angie as a threat to the domestic stability he has created with his wife and daughter. When the affair ends and Flipper tries to earn back his family's trust in Harlem, and Angie returns to the limited horizons of Bensonhurst, we are watching not only the restoration of the racial order, but also the reinscription of idealized middle-class values. The ideology governing the plot dynamic has much more in common with Fatal Attraction than it does with Do the Right Thing.

While Angie stands on one side of Flipper representing the threat of temptation, his crackhead older brother Gator, representing the African American underclass, flanks him on the other side with the fear of falling. All the talk about Bed-Stuy and drugs must have struck the same middleclass nerve that led Lee to write in his production journal: "I'm still deciding whether to include some stuff about drugs. Not to acknowledge that drugs exist might be a serious omission in the film. The drug epidemic is worse than the plague" (Morrison 25). If drugs were a serious omission from Do the Right Thing, then Lee certainly made up for it in Jungle Fever. Given Lee's always active engagement with his critics, it is easy to see Gator as a direct response to the reception of Do the Right Thing. Just in case we don't get it, signs reading "drugs" and "crack" float around Samuel L. Jackson's name in Jungle Fever's opening credits. The critical consensus is that Jackson's portrayal of Gator is the best thing about the film, a judgment that has as much to do with the way that Gator fulfills mainstream expectations as it does with Jackson's performance. In Jungle Fever Lee capitulated to those critics who felt that any portrayal of an African American community must include scores of drug addicts, replacing Buggin Out, Radio Raheem, and Mookie with Gator, his girlfriend Vivian, and a "Taj Mahal" full of addicts whose only concern is to "suck on that glass dick." These people frighten and repulse Flipper at the same time that they reassure the mainstream critical establishment that its decadent, stoned vision of the black community is the correct one. Juxtaposing Flipper, the successful, educated professional, with his brother Gator, who steals from his own parents to buy drugs, confirms the prevailing talk show notion that the inner-city drug problem is strictly one of personal character and choice. Unlike Do the Right Thing, Jungle Fever does nothing to make us question the structural causes of the drug epidemic.

Ultimately, Jungle Fever allows Lee to do the same thing that Nathan McCall does-make peace with the corporate power structure while maintaining a veneer of militant dissent. Lee's movie offers the same choices as Makes Me Wanna Holler (and Superfly ${ }^{13}$ ): between citizen and criminal, angry assimilation and nihilistic addiction. None of these choices poses any threat to power. 
3. For a discussion of how the canonization of African American literature excludes transformationist dissent, see Lyne.

4. For a thorough genealogy of the relationship between white America and black culture, see Lott.

5. The Black Panthers are generally portrayed in mainstream representations as a nationalist and separatist group, but their explicit politics were always Marxist/socialist. See Foner, Seale.

6. For a detailed discussion of the FBI's COINTELPRO war against the Black Panthers, see Churchill and Vander Wall.

7. As Manthia Diawara points out, Lee takes his place in the long relationship between Black independent film and mainstream cinema: ". . . a look at the relations between Oscar Micheaux and the Hollywood 'race films,' Melvin Van Peebles and the Blaxploitation films, Charles Burnett (Killer of Sheep), Haile Gerima (Bush Mama), and Spike Lee and the rethematization of urban life in such films as City of Hope, Grand Canyon, Boyz $N$ the Hood, and Straight Out of Brooklyn reveals that mainstream cinema constantly feeds on independent cinema and appropriates its themes and narrative forms" (4).

8. This distinction between Do the Right Thing and Lee's overall career is reflected in the debate between W. J. T. Mitchell and Jerome Christensen in Critical Inquiry. Mitchell, in "The Violence of Public Art: Do the Right Thing," focuses on Do the Right Thing and finds it oppositional. Christensen focuses on Lee's overall career and finds it "corporate populism."

9. The desire for this sort of ending is expressed in Murray Kempton's review in The Washington Post. " 'Do the Right Thing' is the newest entry in the expanding catalogue of films inspired by ItalianAmerican family virtues. If it is less engaging than 'Moonstruck,' it can be commended for the earnestness of its effort to convey the suffering and final defeat of a rational man by an irrational world" (C3).

10. In 1968, Hoover declared the transformationist Panthers the greatest threat to U.S. domestic security.

11. See Smith 60: "Reviewers and certain viewers grant these films a proximity to and power over real life that is rarely seen in discussions of other types of films. Perhaps the most salient example of this sort of conflation is evident in the panic that surrounded the release of Do the Right Thing. Likewise, law enforcement officers, theater owners, and local merchants all voiced concern that the release of New Jack City and Boyz N the Hood would precipitate gang wars."

12. See Breitman, The Last Year of Malcolm X and "Malcolm as Messiah."

13. We can see the nadir of Spike Lee's capitulation to the ideology that demonizes African Americans and drugs in his adaptation of Richard Price's novel Clockers.

Works Baraka, Amiri. "Spike Lee at the Movies." Diawara, Black American Cinema 145-53.

Cited Breitman, George. The Last Year of Malcolm X: The Evolution of a Revolutionary. New York:

Pathfinder, 1967.

—. "Malcolm as Messiah: Cultural Myth Versus Historical Reality." Marable, Beyond Black and White 137-41.

$\rightarrow$ Christensen, Jerome. "Spike Lee: Corporate Populist." Critical Inquiry 17 (1991): 583-95.

Churchill, Ward, and Jim Vander Wall. Agents of Repression: The FBl's Secret Wars Against the

Black Panther Party and the American Indian Movement. Boston: South End P, 1988.

$\rightarrow$ Davis, Angela. "Black Women and the Academy." Callaloo 17.2 (1994): 422-31.

Diawara, Manthia. "Black American Cinema: The New Realism." Diawara, Black American Cinema 3 25.

Diawara, Manthia, ed. Black American Cinema. New York: Routledge, 1993.

Foner, Philip S., ed. The Black Panthers Speak. New York: Da Capo P, 1995.

Gates, Henry Louis, Jr. "Do the Right Thing: Issues and Images." New York Times 9 July 1989, sec. $2: 1$.

hooks, bell. "Challenging Capitalism and Patriarchy: Third World Viewpoint Interviews Bell Hooks." $Z$ Magazine 8 (Dec. 1995): 37.

Kaufman, Michael T. "In a New Film, Spike Lee Tries to Do the Right Thing." New York Times 25 June 1989: H1+.

Kempton, Murray. "Spike Lee's Self-Contempt." Washington Post 3 Aug.1989: C3.

Klein, Joe. "Spiked?" New York Magazine 26 June 1989: 14-15.

Lee, Spike, et al. Five for Five: The Films of Spike Lee. New York: Stewart, Tabori, and Chang, 1991. Lee, Spike, with Ralph Wiley. By Any Means Necessary: The Trials and Tribulations of the Making of Malcolm X. New York: Hyperion, 1992. 
Lott, Eric. Love and Theft. New York: Oxford UP, 1993.

$\rightarrow$ Lyne, William. "Tiger Teeth Around Their Neck: The Cultural Logic of the Canonization of African American Literature." Arizona Quarterly 52 (1996): 99-125.

Marable, Manning. Beyond Black and White: Rethinking Race in American Politics. New York: Verso, 1995.

$\rightarrow$-. "History and Black Consciousness: The Political Culture of Black America." Monthly Review 47 (1995): 71-88.

Marable, Manning, and Leith Mullings. "The Divided Mind of Black America: Race, Ideology and Politics in the Post-Civil-Rights Era." Marable, Beyond Black and White 203-15.

McCall, Nathan. Makes Me Wanna Holler: A Young Black Man in America. New York: Random, 1994.

$\rightarrow$ Mitchell, W. J. T. "The Violence of Public Art: Do the Right Thing." Critical Inquiry 16 (1990): 880-99.

Morrison, Micah. "The World According to Spike Lee." National Review 4 Aug. 1989: 24-25.

Murray, James P. To Find an Image: Black Films from Uncle Tom to Superfly. Indianapolis: BobbsMerrill, 1973.

Rafferty, Terrence. "Open and Shut." New Yorker 24 July 1989: 78-80.

Seale, Bobby. Seize the Time. New York: Random, 1970.

Simpson, Janice C. "Words With Spike." Time 23 Nov. 1992: 66.

Smith, Valerie. "The Documentary Impulse in Contemporary African American Film." Black Popular Culture. Ed. Gina Dent. Seattle: Bay P, 1992. 58-66.

Sterritt, David. "Spike Lee's Hotly Debated New Film." Christian Science Monitor 27 June 1989: 7.

Van Pebbles, Melvin. "Right On, As in Right on Time." Lee, Five 6-7.

West, Cornel. Keeping Faith: Philosophy and Race in America. New York: Routledge, 1993.

-. "Marxist Theory and the Specificity of Afro-American Oppression." Marxism and the Interpretation of Culture. Ed. Cary Nelson and Lawrence Grossberg. Urbana: U of Illinois P, 1988. 17-31.

Williams, Juan. "Why Spike Lee's New Film Ultimately Fails." Washington Post 25 June 1989: G1+. Williams, Patricia J. The Alchemy of Race and Rights. Cambridge: Harvard UP, 1991.

\section{AFRICAN AMERICAN REVIEW IS NOW AVAILABLE IN JSTOR!}

JSTOR, a not-for-profit organization, is an exciting endeavor dedicated to helping the scholarly community take advantage of advances in electronic technologies. The JSTOR database consists of the complete backfiles of a number of scholarly journals and is available to researchers through participating libraries.

In addition to African American Review, African-American studies journals presently available in JSTOR include: Callaloo, The Journal of Blacks in Higher Education, Journal of Negro Education, and Journal of Negro History.

Information regarding J STOR is available at http://www.jstor.org. as is a demonstration version of the database.

120 FIFTH AVENUE, NEW YORK, NY 10011 